\title{
Innovative approaches to ESL for young learners: South Africa and the United States
}

\section{Adrienne Rumboll}

\begin{abstract}
An experiment in the teaching of English L2 to young (pre-primary and primary) children is described. There was a high tutor-to-pupil ratio, but tutors had had no previous experience of teaching at this level. The planning of the lessons and their execution are outlined and the use of activities such as Total Physical Response described. The eclectic nature of these approaches is emphasised and suggestions about the development of further co-operative activities are made.
\end{abstract}

\begin{abstract}
Die skryfster beskryf 'n eksperiment ten opsigte van die onderrig van Engels as tweede taal aan jong (d.w.s. pre-primêre en primêre) kinders. Die onderwyserleerling-verhouding was hoog, maar die onderwysers het geen vorige ondervinding van onderwys op dié vlak gehad nie. Sy beskryf die beplanning en aanbieding van lesse asook die gebruik van aktiwiteite soos die "Total Physical Response". Die eklektiese aard van hierdie benaderings word beklemtoon en voorstelle rakende die ontwikkeling van verdere koöperatiewe aktiwiteite word gemaak.
\end{abstract}

Could young Vietnamese refugees in America and children from South Africa have anything in common as far as ESL is concerned? In this one instance, certainly, both receive ESL instruction in unusual and innovative contexts. In Ames, Iowa, Jacque Zbaracki has taken her pre-school group of frightened, silent refugees and has provided a setting and means by which they have become confident, communicating youngsters. The same has happened to timid young ones in South Africa where a group meets on an informal, community basis on a Saturday morning. I shall deal with the South African class in detail and then link it with the United States group, concluding with some recommendations for South Africa.

Origin of the class in S.A. The idea of the class originated with some of the parents in Mangaung Township who wanted their children to become confident and skilled in English at a young age in order to be equipped for the South Africa of the future. They approached members of the English Department at the University of the Orange Free State where Albert Weideman responded enthusiastically to the challenge.

The project. Initially there was much uncertainty, as none of the tutors had experience of teaching such young children or such an age range (5-10 years old). They were, therefore, not clear about the level of proficiency to aim at, how much they could accomplish in the given hour, what would interest the children, or how the latter would react.

The tutors decided on an eclectic approach based on humanistic principles, physical activities, and language games and songs. Gertrude Moskowitz's ideas and strategies in Caring and Sharing in the ESL Classroom (Moskowitz, 1984) helped to counter the children's shyness and inhibition. Another 
source was Asher's Total Physical Response approach, which stresses language learning via actions and appropriate physical responses, with language production only coming later. "The teacher provides opportunities for learning and controls the language input" (Richards and Rodgers 1986:94) or, as Asher puts it, "The teacher gives commands which the pupils carry out in a variety of ways" (Asher 1977). The tutors also drew on their own resources of language games and songs which could be adapted. Flexibility was to be the key word in achieving their aim of maintaining the interest and utilizing the abilities of the children, as well as in using the allotted time productively.

Participants. There was a core group of about 14 Tswana- and Sotho-speaking children from Mangaung who came every Saturday morning to Albert Weideman's home for an hour's class. They varied in age and also in their knowledge of English. A few (4-6) of the tutors' children completed the group. They were in the upper age range, and their exposure to and knowledge of English was greater. Their participation was important because their presence would make the other children feel more at home; they could serve as peer models so that the children would learn to play together and to cooperate. The tutors were mainly from the English Department of the University of Orange Free State and from Teachers' Colleges. (G.J. Orr, a visiting scholar from the University of California in Los Angeles, played a leading role in the initial stages of the project). Although the ratio of 6 tutors to about 18 pupils was high, it was much needed.

Class sessions. For the crucial first session (August 9, 1986), they decided to begin with the usual greetings and introductions (Hello. I'm . . . How do you do?), but to make a game of it by using a non-threatening ball. (One of paper and masking tape was made in front of the children.) The holder of the ball would say his/her name as he/she gently tossed the ball to the next person. The children would also play photographer and "take pictures" with their imaginary cameras to lead to a photographic session which would help identify and involve children sooner. At the end they would practise their greetings again.

The post-session evaluation revealed that all the tutors, two per group, were greatly needed and involved. The ball game was a problem until one tutor explained in Tswana that they should say their names when they caught the ball. It might be that they didn't recognise the tutors' Gregory, Ermien, Wilfred, and Marius as names. More time was used than anticipated on introductions, so the number of activities had to be reduced and simplified. It was also realised that a refreshment break would help retain attention.

For session two, the tutors planned repeating the greetings and introductions, followed by a variety of Total Physical Response activities ("Come and sit next to me" / "Pick . . ." " Touch . . ."), leading to the song "Head and Shoulders, Knees and Toes" being acted and sung by the children.

In the actual session it was found that the ball game worked well but took time. In the "Come and sit next to me" exercise all children could respond to the request but some could not produce the request themselves. The introduction of colours revealed that most children knew them. As the tutors had also planned "Touch eyes, ears, head and nose ...", followed by the song "Head and Shoulders, Knees and Toes", for which there was no time, they realised that they should spend more time on fewer activities, and that they should continue to probe and challenge to discover where the pupils had difficulties (for example, with "Come and sit beside me").

In session three, the identification of parts of the body, as well as the introduction and practice of the song omitted previously, went well.

In session four, there were again activities aimed at a mid-level ability. By now the tutors felt that they were beginning to plan such activities realistically. This time they managed to review the song "Head and Shoulders . ..." and introduce concepts of square and circle as well as a poem: "Here's a house built up high, Here's a chimney up to the sky, Here's a door open wide, Here's the man who lives inside", accompanied by a large drawing of this house. The children acted and said it with the 
teacher while those who could, read it at the same time. A new song, mime variation "Where is Thumbkin, Where is Thumbkin? Here I am, Here I am" was also introduced.

After four sessions the tutors felt 'exhilarated' (Orr 1987) as their flexibility in adapting their strategies and activities all along was working. Their basic approach seemed to be 'sound and effective' (ibid.). The non-threatening atmosphere was setting children at ease: they were developing confidence in their ability to communicate, making progress in their language learning, and were very keen and interested each week.

Since then the writer has observed the group and has been involved in the planning and evaluation sessions. Out of this initial period a more settled structure has been evolved. The warm, familiar introduction is there, as a song: "Where is . . Where is . . . Come and stand beside me, Come and stand beside me". One member after the other invites one of the rest to join the group so that all are finally holding hands and singing. This is followed by a review of a dramatised poem. Then attention is focused on TPR command-based activities and questions. They have progressed through simple commands, e.g. "Stand up. Turn around. Raise your left hand", to shapes and colours, the parts of the body, numbers, and sequence. The house, its inhabitants, and their activities followed next. The children were led from the outside structure by means of a drawing, and later an actual model house and objects, to discover the various rooms, objects and occupants, as well as the activities inside and around the home. In all the phases the tutor directs and instructs, using mime, pointing, and context. This is followed by pupils working in pairs or groups as in the information gap-type game where they, for example, sit back-to-back and draw, find, or place according to commands or questions by partners.

During this group work stage, the younger ones go to a pre-school tutor who entertains them by telling a story which they will illustrate by drawing, painting, cutting, or shaping. After break, the poster-file is used again for a picture and the words of a rhyme that will be acted and read/said, imitating the tutor. (For example, "This is the chimney that reaches the sky; This is the door opened wide...") Pupils review a song and/or learn a new one, based on the theme of the moment. Tutors take turns leading class activities and are all involved in pair or group work.

The session is rounded off with a story greatly dramatised for all by the pre-school teacher. This is linked with the activities of the day. For example, when they brought items of their clothing and tried to identify them (miming, pointing, mouthing from a tutor), the story was about the man who sold hats and who rested under a tree in which many monkeys lived.

In summing up at this stage, after about 8 months, one would perhaps share the 'exhilaration' evinced after the first few sessions. This widely differing group - as far as age, culture, and proficiency are concerned - have become a happy working unit. Many factors have contributed to this: The informal and relaxed setting in and around a home; sufficient tutors who are friendly and interested, building a non-threatening atmosphere, yet challenging the participants to continually discover and grow.

The eclectic approach of combining TPR activities, the humanistic, caring approach, the careful choice of language games and activities, plus dramatised songs, poems and stories has kept the children actively involved up to where they are finally producing English themselves. One's overriding impression is that, more important than the actual language acquisition, which has been very satisfactory, is the change in attitude and expectations of this group. From being diffident and quiet they have become confident, relaxed youngsters who are ENJOYING themselves.

Jacque Zbaracki has experienced exactly the same with her Vietnamese pre-schoolers in Ames, Iowa. As refugees they desperately needed to communicate; to make contact in their strange, new world; to feel some security and warmth. And this led her to an English acquisition approach instead of just the normal pre-school activities. She also provides a friendly, encouraging atmosphere; nonstress, non-demanding situations, and uses many stories, songs (for example, the very same "Head and Shoulders..." of the South African group), pasting and cutting as a magic mix to build 
confidence, develop a basic vocabulary, and teach how to interact socially; to be at ease. She has seen her group grow and develop over a period of three years. She has also evaluated their achievements by means of the Peabody Picture Vocabulary Tests to good effect. We propose to use this test for our group in South Africa but to supplement it with information-gap and dialogue situations.

Bearing both these groups in mind, those parents, teachers, and community leaders interested in such an informal, co-operative approach might find the following recommendations useful:

Group the children according to their proficiency level as soon as possible to individualize instruction, taking shyness into account.

Activities should be varied, should inform, but above all, should allow children to participate and have FUN.

Flexibility should be the watchword. Be guided by the children's responses and their needs.

In South Africa the multi-cultural composition of such a group should be a priority. Children should be learning, communicating, and playing naturally together.

Although there is much to learn about ESL in the young, especially as regards effective communicative testing of such groups, Jacque Zbaracki and the South Africans feel that they have made a meaningful start in the right direction.

\section{References}

ASHER, JAMES J. 1977. Learning another language through actions: the complete teacher's guidebook. Los Gatos, Calif.: Sky Oaks Productions.

CARRIER, LAURA \& T. Henderson. 1985. Classroom roles of the ESL teacher: teacher as parent. Video. Department of English/ESL, Iowa State University.

MOSKOWITZ, GERTRUDE. 1984. Caring and sharing in the ESL classroom. Rowley, Mass.: Newbury House.

ORR, GREGORY J., W.J. Greyling, M. Pretorius, E. van Pletzen \& A.J. Weideman. 1987. Saturday morning in town. South African Journal for Language Teaching, Vol. 21 No.3.

RICHARDS, JACK C. \& Theodore S. Rodgers. 1986. Approaches and methods in language teaching: a description and analysis. Cambridge University Press. 